Terbit setiap Januari dan Juli

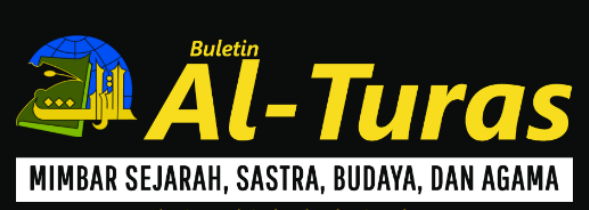

ISSN : 0853-1692

\title{
Al-Nahwu 'Inda al-Bashriyyiin wa al-Kufiyyiin (al-Qarn al- Awwal ila al-Tsalits al-Hijriy)
}

\author{
Ahmad bachmid
}$$
\text { ملخص البحث }
$$$$
\text { كانت في نشأة النحو العربي أدوار، الدور الأول الوضع والتكوين، وهذا من دور البصرة، وهي أول مدينة عينت بالنحو واللغة، تبدأ }
$$

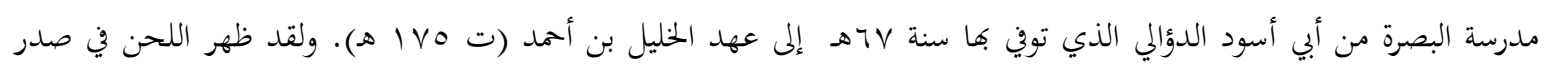$$
\text { الإسلام بسبب اختلاط العرب وامتزاجهم بالأعاجم، مما جعل علماء البصرة يحرصون على رسم أوضاعها خوفا عليها من الفناء }
$$

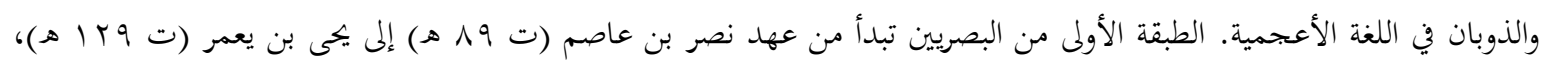$$
\text { والطبقة الثانية من البصريين فن الدور الأول تبدأ هذه الطبقة من عهد عبد الله بن إسحاق (ت IV هـ إلى عهد أبى عمرو بن العلاء }
$$$$
\text { (ت عه ا هـ). الدور الثانى : دور النمو والنشوء والارتقاء، وهذا من دور البصرة والكوفة، وقد سبقت البصرة بنحو مائة عام الكوفة }
$$$$
\text { التي جاءت بعدها لتأسس مذهبا خاصا في النحو. تقابل الطبقة الثالثة من البصريين الطبقة الأولى من الكوفيين، ومن أشهر علمائها أبو }
$$

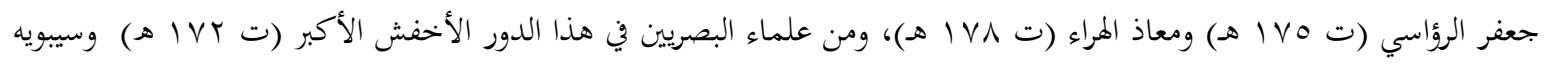$$
\text { (ت · 1 1 هـ). الدور الثالث دور النضج والكمال، لقد بلغ النحو نضجه وكماله فأصبحت القضايا النحوية علما مستقلا. }
$$$$
\text { الكلمات المفتاحية: النشأة، النحو، البصرة، الكوفة }
$$

\section{Abstrak}

Dalam perkembangan ilmu nahwu, terdapat beberapa fase, fase pertama peletakan dan penyusunan. Ini berpusat di Bashrah, sejak peletakan pertama oleh Abu al-Aswad sampai al-Khalil ibn Ahmad. Pada waktu itu lahn telah tersebar luas sehingga menuntut mereka untuk segera mengkodifikasi nahwu. Terjadinya lahn diseabkan oleh interaksi bangsa arab dengan bangsa-bangsa lain di dunia. Periode pertanma bashrah dimulai pada masa Nasr Ibn Ashim (w.89 M) sampai masa Yahya Ibn Ya'mur (w. 129 H). Periode kedua Bashrah dimulai dari masa Abdullah Ibn Ishaq (w. 117 H) Sampai masa Amr Ibn al-Ala (w. 154 H). Kedua, masa pertumbuhan, yaitu masa perkembangan di mana nahwu bukan hanya berkembang di Bashrah melainkan pula di Kufah. Tokoh Kufah pada fase ini antara lain Abu Ja'far al-Ru'asi (w. 175 H) dan Muazd al-Harra (w. 178 H), sedangkan tokoh Bashrah antara lain al-Akhfasy al-Akbar (w. 172 H) dan Imam Sibawaih (w. $180 \mathrm{H}$ ). Ketiga, fase kematangan dan penyempurnaan, dimana ilmu nahwu telah telah dikodifikasi oleh ulama-ulama di kedua kota tersebut.

Kata Kunci: Pertumbuhan, Nahwu, Kufah, Bashrah
\end{abstract}


Al-Nahwu 'Inda al-Bashriyyiin...

كان اخطلاط العرب بغيرهم قبل الإسلام نادرا جدا،

وكان منحصرا فن تجارةم نحو اليمن والشام. قد أراد

الله عز وجل تخليد ذكرياهم بسورة خاصة بين دفنى القرآن الكريم وسماها سورة قريش. وهما هى فيما يلى:

أعوذ بالله من الشيطان الرجيم

$$
\text { بسم الله الرحمن الرحيم }
$$

لإيلاف قريش ( 1 ) إيلافهم رحلة الشتاء

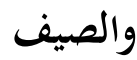

(Y) فليعبدوا رب هذا البيت (ب) الذى

\section{أطعمهم من}

\section{جوع و آمنهم من خوف (ع).'}

فضلا عن بحاورتم بالفرس والروم ولم يكن

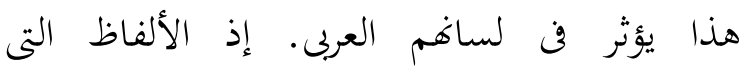
يستعملوفا في معاملتهم مع هؤلاء مقصورة على حدود بيع أو شراء أو رفض أو قبول وما إلى ذلك من أداة أسلحة وأسماء سلعة. تلك الألفاظ لا تؤثر تاثيرا كبيرا فن لغتهم التى تجرى في كياهم بحرى الدم في العروق فلم نصب لغتهم بداء اللحن إلا قليلا. ولم يكن هذا القليل داعيا إلى وضع حد له فإنه لا يمثل الخطورة الكبيرة على اللغة وإنما يمثل خطورة إذا زاد

$$
\text { 'القرآن : سورة قريش }
$$

$$
\begin{aligned}
& \text { وانتشر واستشرى في ألسنتة بعض العرب وفصحاء }
\end{aligned}
$$

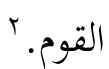

$$
\begin{aligned}
& \text { ومن هنا نستطيع أن نضع ثلاثة أسئلة: } \\
& \text { الأول : لماذا وضع النحو؟ }
\end{aligned}
$$

الثانى : هل كان اللحن معروفا في الجاهلية وفى عهد رسول الله صلى الله عليه وسلم؟

الثالث: ما مظاهر انتشار اللحن التى جعلت الغيورين على دينهم يشعرون عن ساعد الجحد في وضع قواعد النحو؟

$$
\text { ويمكن تلخيص الإجابة كالآتى : }
$$

لانتشار اللحن ولغيرة المسلمين وحرصهم

على لغة دينهم لغة القرآن الكريم. كما يمكن إيجاز الإجابة عن السؤال الثان بنعم. لأن اللحن كان معروفا فن الجحاهلية وفى عهد الرسول وفى عهد خلفائه

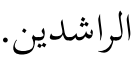

والجواب عن السؤال الثالث : أن انتشار

الإسلام وكثرة الفتوحات ودخول الناس في دين الله أفواجا، واختلاط غير العرب بهم واختلاط العرب بغيرهم سبب فن ظور اللحن الذى جعل المسلمين يشعرون على الساعد لوضع قواعد النحو.

يكاد يكون يتفق النحويون أن أبا الأسود الدؤلى له المجهود الأكبر في وضع علم النحو، ولو لم

بحمد الشاطر أحمد محمد، الموجز فى نشأة النحو، القاهرة

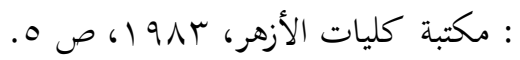


يكن معروفا في عهده لقب النحو، بل كان معروفا بعلم العربية. ومن ثم كانت التسمية بالنحو في عهد أبى الأسود الدؤلى تسمية بحازية مبنية على الاتساع فلم تحدث هذه التسميةإلا فن وقت متأخر. وقيل جاء على هذا الاسم لما قال الإمام على كرم الله

$$
\text { وجهه لأبي الأسود الدؤلي : }
$$

\section{تعريف النحو لغة واصطلاحا :}

النحو بمعنى الجانب والطريق والقصد. وأما

فن الاصطلاح فهو علم يعرف به كيفية التراكيب العربية الصحيحة يتعلق بألفاظ من حيث وقوعها فيه. وقيل هو قواعد بها تعرف أحال الكلمات العربية

$$
\text { إعرابا وبناء. }
$$

إن الدراسات القرآنية فن بجال النحو

والقراءات كان له أثر كبير في قواعد علم النحو.

'الدكتور يوسف أحمد المطوع، الموسوعة النحوية الصرفية،

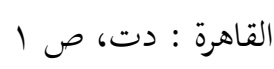

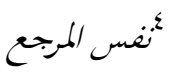

ألدكتور أحمد مكى الأنصرى، الدراسات اللعوية النحوية،

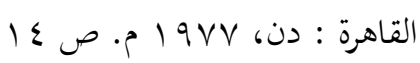

وقد تطلق كلمة النحو لغة ويراد بها واحد

من خمسة معان : من

1- المعنى المشار إليه وهو القصد، يقال :

$$
\text { نهوت نحوك أى قصدت قصدك. }
$$

r- المثل، نخو : مررت برجل نغوك، أى

مثلك.

ب- الجهة، نحو : توجهت نحو البيت أى

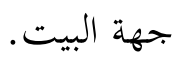

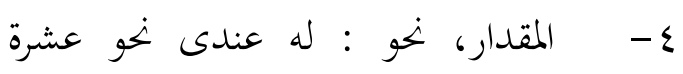

جنيهات أى مقدار عشرة.

- - - القسم، نهو : هذا الموضوع على أربع

$$
\text { أنخاء، أربعة أقسام. }
$$

$$
\text { اللحن : (الت : }
$$

اللحن الذى يراد ذكره فن هذه المقالة والذى

سعى نوع من التأليف فن اللغة العربية، هو

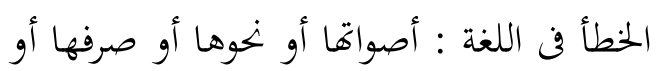

$$
\text { معانى مفرداتا. ve }
$$

ولعل أول معنى لهذا اللفظ هو ما ذكره أحمد

بن فارس. فأما اللحن بسكون الحاء، فإمالة الكلام عن جهة الصحيحة في العربية، يقال : لحن لحنا،

$$
\begin{aligned}
& \text { †الدكتور محمد عمى السمان، اليسير، مكتبة جامعة }
\end{aligned}
$$

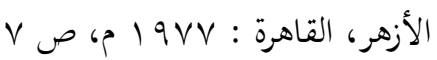

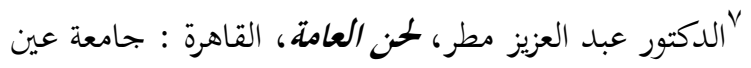

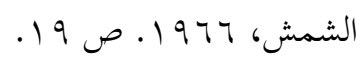


Ahmad bachmid

Al-Nahwu 'Inda al-Bashriyyiin...

وهذا من الكالام المولد، لأن اللحن محدث، لم يكن

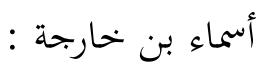

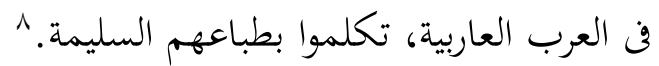
\#نطق رائع وتلحن أحيا ت

فكانت للفظ الآلات الآتية :

أولا : الغناء وترجيح الصوت والتطريب. والمنى العام نا وخير الحديث ما كان ملحوظ في هذه الدلالة، إذ هى إزالة الكام عن

جهة الصحيحة بالزيادة والنقصان في الترقيم. ومن شواهد هذا المعنى قول يزيد بن النعمان

فقد فسر الجاحظ اللحن هنا بالخطأ، وتابعه في ذلك ابن قتيبة وابن عبد ربه. 'r ثالثا : اللهجة الخاصة

لقد تركت فؤادك مستجنا

وقد استشهد أبو بكر ابن الأنبارى وأبو على القالى على أن معنى اللحن اللهجة.

مطوقة على فنن تغنى

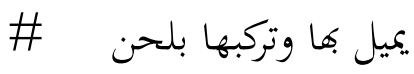
يقول على بن عميرة الجرمى :

وما هاج هذا الشوق إلا

ماحة

إذا عن للمحزون أثنا

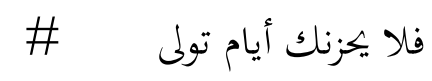

تبكت

$$
\text { على خضراء سمر قيودها }
$$

تذكرها ولا طير أرنا.' - ت

هتوف الضحا معروفة

والمراد به اللحن الذى هو ضرب من الأصوات

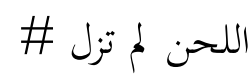

المصوغة للتغى،

والدليل على ذلك قوله : مطوقة على فنن تغنى.

تقود

الهوى من مسعد ويقودهاr'

ثانيا : الحطأ في اللغة

المراد بقول معروفة اللحن هى اللهجة أى

ويعد من الشواهد على اللحن بمعنى الخطأ

عند بعض العلماء قول مالك بن

$$
\text { "ن "نفس المنس المرجع }
$$

$$
\begin{aligned}
& \text { "انفس المرجع، ص Or . }
\end{aligned}
$$

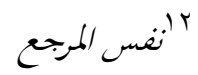

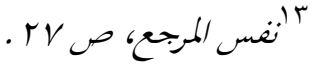


هذه هي المعان التى وردت لمادة لحن في

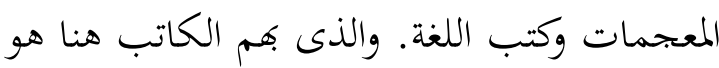

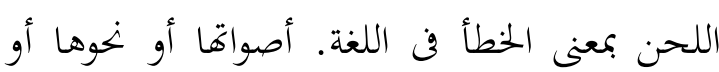

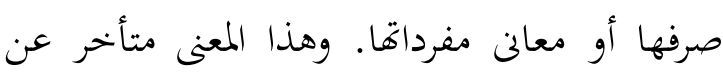

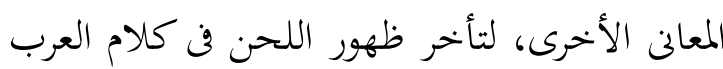

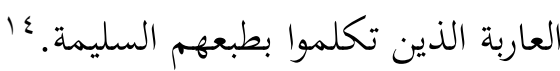

نشأة اللحن

إن اللحن في معنى الخطأ فن اللغة العربية قد

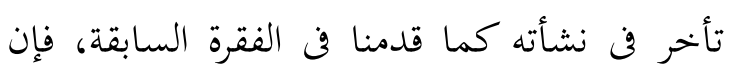

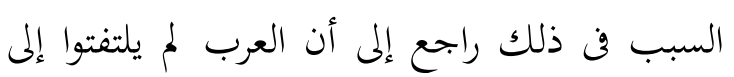

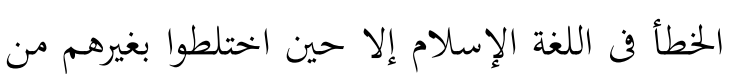

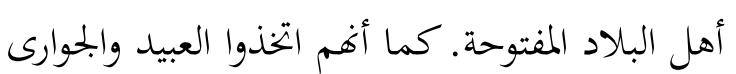

لإرادة المنازل في العصر الإسلامى المبكر . لمادئ.

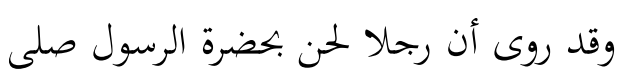

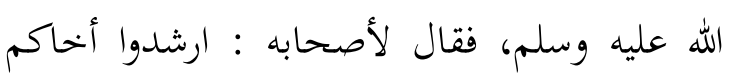
فإنه فقد ضل. 10

وقد جمع الدكتور عبد العزيز مطر هب مسألة مما ورد في اللحن في أوائل نشأته في كتاب البيان والتبيين

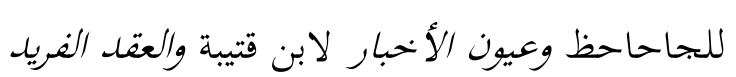

$$
\text { لابن عبد ربه. } 17
$$

أما حالات الخطأ في الإعراب فقد رويت

عن شخصيات عربية معروفة بأسمائها كالحجاج بن الاعراب فلد روبت

$$
\begin{aligned}
& \text { ؛'الشيخ أممد الإسكندرى ومصطفى عنان، الوسيط، }
\end{aligned}
$$

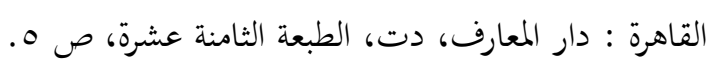

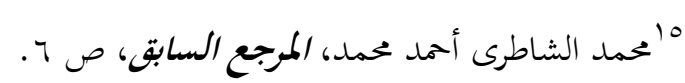

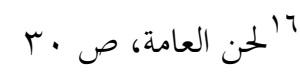

يوسف والوليد بن عبد الملك وبشر بن مروان وخالد

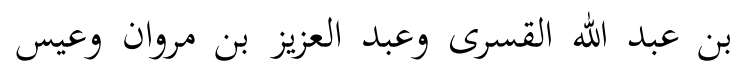

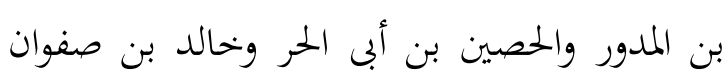

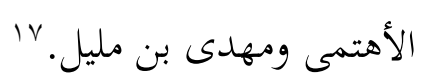

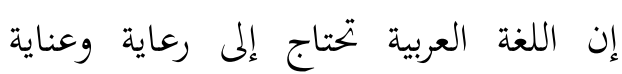

وحفظ لأغا لغة القرآن والحديث وبرعايتها تحفظ

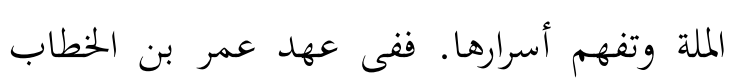
(ولد ·ـ ق هـ وتوف r r هـ) حدث أن أعرابيا طلب أحدا أن يقرئه شيئا من القرآن الكريم، فأقرأه

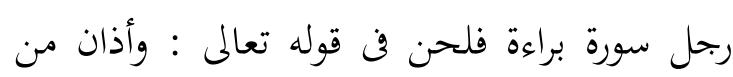

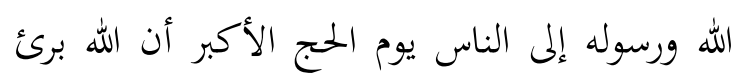
من المشركين ورسوله. 11 حيث قرأ بكسر اللام في " رسوله " فقال الأعرابى أو قد برئ الله من رسوله؟ إن يكن الله قد فـ

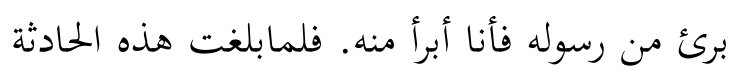

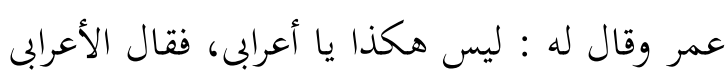

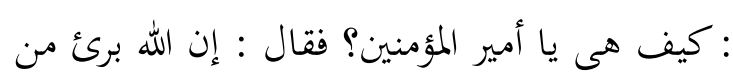
المشركين ورسوله بالرفع، فأمر عمر بعد ذلك ألا يقرأ القرآن إلا عالم باللغة. 19

وروى أيضا أن كاتب أبي موسى (ت عـ ـهـ

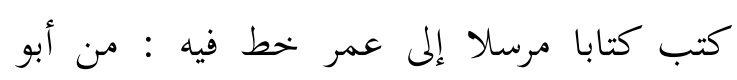

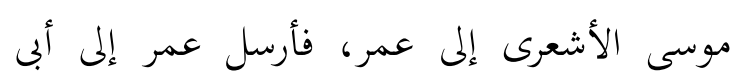


Al-Nahwu 'Inda al-Bashriyyiin...

موسى : بأن يضرب كاتبه سوطا ويؤخر عطاه

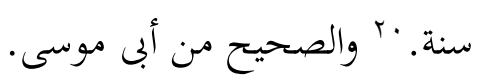

\section{أول من وضع النحو}

اختلف العلماء قديما وحديثا فن أول من وضع

$$
\text { النحو، وفيما يلى بعض آرائهم : }
$$

أولا : قيل إن أول من وضع علم العربية

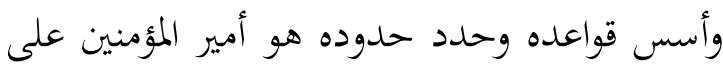

بن أبى طالب. وهو أول من بدأ استقراء اللغة

واستنتاج أقسام الكلام منها : وهى الاسم والفعل

والحرف. ابثم كلف أبا الأسود الدؤلى أن يستأنف

العسيرة ويتابع العمل وينحو نهوه في الاتقراء

$$
\text { والاستنتاج. }
$$

ثانيا : قيل إن أول من وضع النحو أبو

الأسود الدؤلى (ت VI هـ بإشارة من زياد بن أبيه

$$
\text { rr. (ت ه O (ت ) }
$$

ثالثا : قيل أن أبا الأسود أصر على وضع

النحو حينما قالت له بنته في ليلة كثيرة النجوم، ما لـ أحسن السماء؟ بضم نون أحسن وكسر همزة

السماء، فقال نجومها : حيث ظن أفما تستفهم. فتحيرت لها خطؤها فعلم أبو الأسود أغها

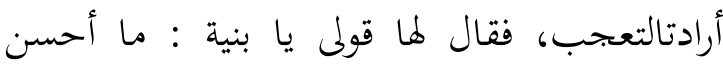

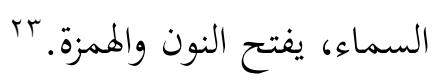

رابعا : يرى أحمد بن فارس وأبو على

الفاسى أن وجود النحو بتوفيق من الله واستدلوا

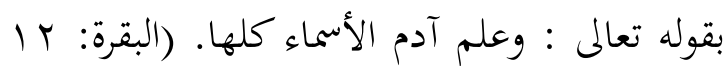

$r \leqslant(r q$ :

والجدير بالذكر أن أبا الأسود الدؤلى له دور

كبير في وضع الحجر الأساسى على النحو. سواء

من أمر نفسه أو أمر عمر أو من أمر على بن أبى طالب أو من أمر زياد على الخلاف السابق في ذلك، وهم كانوا على علم بمعرفة أبى الأسود الدؤلى على اللغة العربية وعلومها.

وأبو الأسود الدؤلى هو أول من بدأ بنقط

المصحف وهو ما يقوم مقام الشكل بالحركات الآن. وذلك بوضع نقطة على أعلى الحروف لتدل على الفتحة أو بين يدى الحرف لتدل على الضمة أو تحته لتدل على الكسرة، ويجعل النقطة نقطتين كذلك لتدلا على التنوين. ro نشأة النحو عند البصريين قد اتفق العلماء أن العراق كانت مهدا لنشأة النحو، ولا عجب إذا قيل إن مهد نشأته كان في البصرة بين العراق الثلاث بل لقد احتضنت البصرة النحو زهاء قرن من الزمان قبل أن تشتغل به

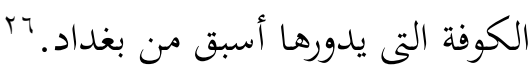

$$
\begin{aligned}
& \text { ك أنفس المرجع، } 11 . \\
& \text { ج" الدكتور محمد على السمان، المرجع السابق، ص } 9 .
\end{aligned}
$$

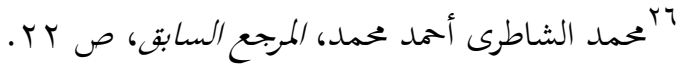


ويمكن إيجاز أسباب أسبقية البصرة على

غيرها من مدن العراق فن الاشتغال بالنحو فيما يلى: - n

$$
\text { أولا : السياسة }
$$

كانت البصرة عثمانية أموية، وكانت الكوفة

علوية عباسية. فلقد هبط على بن أبى طالب كرم

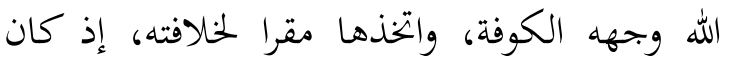
أهل الكوفة مطيعين له فدعوه إليهم فن الوقت نفسه شق فيه أهل البصرة عليه عصا الطاعة. فقد جاءت السيدة عائشة (تمهـه) رضي الله عنها البصرة، ومعها جيش طلحة (تדب هـ) والربير (ت بr هـ) مطالبين بثأر عثمان (0ب هـ /

$$
\text { rV. }(5707
$$

فاستمرت البصرة هاشمية عثمانية والكوفة قرشية علوية. ولما كانت مهزلة التحكيم والغالب فيها الأمويون كان طبيعيا أن يكون الاستقرار والطمأنينة والهدوء للبصريين.

\section{ثانيا : الموقع الجغفافى}

تقع البصرة على طرف البادية يلى العراق في

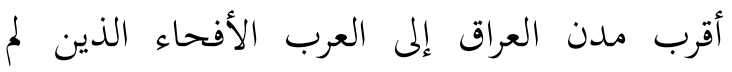
تلوث لغتهم بعامية الأمصار، فعلى مقربة منها بوادى بند غربا والبحرين جنوبا، فسهل على أهل

$$
\text { لنَّنس المرجع المرجع }
$$

البصرة الاتصال بهم دون أن يتكلفوا مشاق السفر والمحنة والعناء.

$$
\text { ثالثا : قرب سوق المربد من البصرة }
$$

إذ كانت تنعقد فيها بحالس للعلم والمناظرة، ويفد فيها الشعراء ورواتم فهى تشبه سوق عكاظ في الجاهلية ينزل فيها الشعراء والأدباء والأشراف للمذاكرة والرواة والوقوف على ملح الأخبار واللغويون يأخذون على أهلها ويدونون ما يسعون

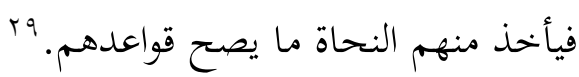
والجدير بالذكر أن البصرة مرفأ تجارمى للعراق على الخليج العربى. فقد نزل إليها عبد الله بن إسحاق الحضرمى من أول النحاة البصريين بالمعنى الدقيق لهذه الكلمة. ·r

وقول ابن النديم : إنما قدمنا أهل البصرة أولا لأن علم العربية أخذ. ابمهما قيل فإن أهل الكوفة التخذوا البصرة متتلمذا لهم حتى يسر الله لهم من شعارة النصيب الأفى، فاشترك علماؤهم مع علماء البصرة من النهوض به فن عهد الخليل بن أحمد (ت

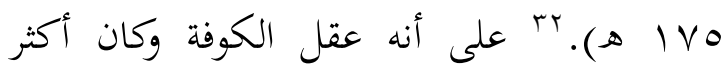

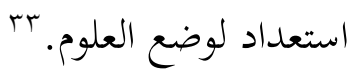
وما كان بين القراءات من خحلافات في في الإعراب هو الذى أضرم الرغبة في نفوس قراء البصرة

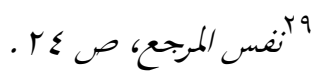

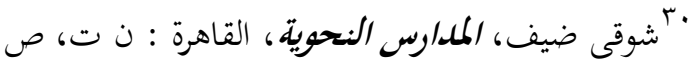


Al-Nahwu 'Inda al-Bashriyyiin...

كى يضعوا النحو وقواعده وأصوله حتى يتبين القارئ مع الكلم في آية القرآن الكريم من الإعراب

$$
\text { المضبوط الدقيق. }
$$

والحق أن المدرسة البصرية كانت أدق حسا

من مدرسة الكوفة فن الفقه بدقائق العربية وأسرارها.

فقد تعمقت ظواهرهاوقواعدها النحوية والصرفية

تعمقا أتاح لها أن تضع نحوها وضعا سديدا قويما. ومن أشهر علماء النحو سبويه الذى أخذ

النحو من الخليل بن أحمد، وقد وضع كتابه المشهور الكتاب جامعا فيه ما نقله عن أستاذه، ولقد عظم شأن الكتاب حتى صار علما بالغلبة عليه، وسمى

$$
\text { قرآن النحو. عان النعاب }
$$

الدور الأول : دور الوضع والتكوين

يؤرخ العلماء لهذا الدور بعد أبى الأسود

الدؤلى بنصر بن عاصم الليثى (ت 19 هـ) إلى

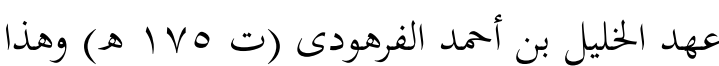
دور بصرى خالص. وبرز فيهما طبقتان من علماء

$$
\text { البصرة وها هما : }
$$

$$
\text { الطبقة الأولى من البصريين : }
$$

تبدأ من عهد نصر بن عاصم (ت 9 م هـ

$$
\text { إلى يحى بن يعمر (ت 9 ب ا هـ). }
$$

(1) نصر بن عاصم الليثى (ت 9 (ت هـ)، كان فقيها عالما بالعربية فصيحا وبعد من قدماء التابعين،

$$
\text { أخذ القرآن والنحو عن أبى الأسود الدؤلى. ro }
$$

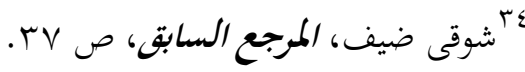

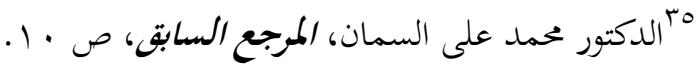

r) عنبة الفيل، وهو رواة الشعر (ت . . 1 هـ) بr ب) عبد الرحمن بن هرمز (ت IV هـ مدلن، أخذ القراءة عن عبد الله بن عباس (ت TV ه)، وأخذ العربية عن أبى الأسود الدؤلى،

وكان من أعلم الناس بالنحو وأنساب قريش، كما أهل المدينة أخذوا النحو منه. rv

ع) يجيى بن يعمر العدوانى (ت و ب ا هـ)، كان

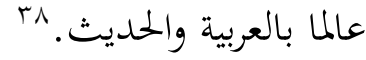
فكان منهج هذه الطبقة مبسطا، إذ وضع أبو الأسود القواعد العامة مقصورة على السماع، ولم تعلنا عن هذه الطبقة كتب منظمة يمكن الاعتماد عليها. وفى عهد عبد الملك بن مروان قام نصر بن عاصم بإعجام المصحف بالنقط المعروفة الآن بعد أن أصلح من النقط التى وضعها أبو الأسود الدؤلى لتدل على جهة الصوت. وذلك بتحويلها إلى الحركات المعروفة فحلت نقط نصر بن عاصم محل نقط أبى الأسود وتحولت نقط أبى الأسود إلى الآن حتى يرث

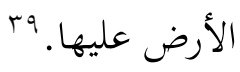
الطبقة الثانية من البصريين فى الدور الأول :

$$
\begin{aligned}
& \text { بrممد الشاطرى أحمد محمد، المرجع السابق، ص اعـ. }
\end{aligned}
$$

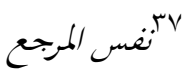

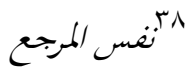

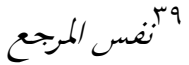


تبدأ هذه الطبقة من عهد عبد الله بن إسحاق (ت

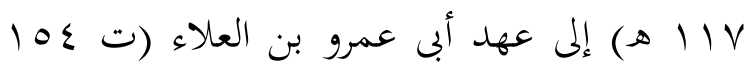
ه). •؛ ومما يلى سيذكر الكاتب أسماء علمائها المشهورين : ( ) عبد الله بن أبى إسحاق الحضرمى إمام في القراءة

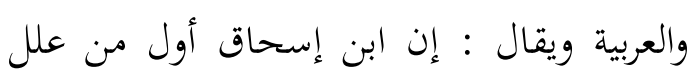

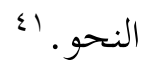

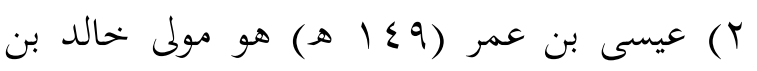

الوليد المخزومى نزل في ثفيق وهو معدود من قراء

البصرة ونحاتها، وعنه أخذ الخنليل بن أحمد، وله في

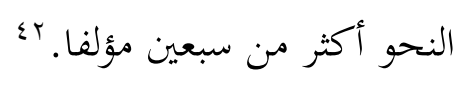

r) أبو عمرو بن العلاء بن عمار بن عبد الله المازنى

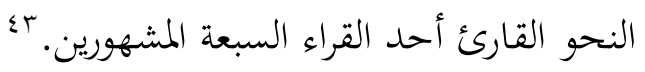

\section{منهج هذه الطبقة وأثرها :}

(1) هجت هذه الطبقة منهج الاستنباط

واستعمال القياس فوضعت كثيرا من أصول

النحو ومسائله واقتصرت مباحثهم على ولى

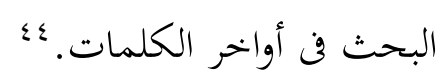

Y) امتزجت مباحث النحو فيها بمباحث اللغة

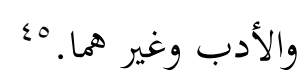

ب) فلقد ذهب أبو جعفر الرؤاسى (110 هـ)

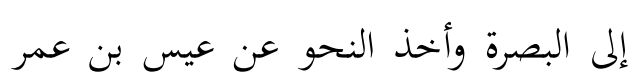

$$
\text { وأبى عمرو بن العلاء. بـ }
$$

الدور الثانى : دور النمو والنشوء والارتقاء

أولا : الطبقة الثالثة البصرية :

- - الأخفش الأكبر ( IVT) هـ أبو

الخطاب عبد الحميد بن عبد المجيد

الأخفش الأكبر، كان إماما في العربية

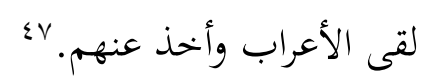

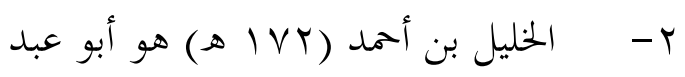

الرحمن بن أحمد تميم الفرهودى نسبة إلى إلى

فراهيد اليمن، وهو أول من استخرج

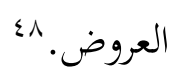

r- يونس بن حبيب (r) إ هـ) وهو أبو عبد الرحمن يونس بن حبيب الضبى الولاء من أكابر النحويين.

ثانيا : الطبقة الرابعة البصرية بشر عمرو بن عثمان بن قمير، ولد في البيضاء قرب شيراز وتوفى فيها. كان منشأه

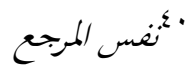

$$
\begin{aligned}
& \text { أنغس المرجع لغن المجع }
\end{aligned}
$$

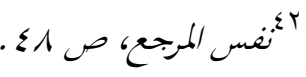

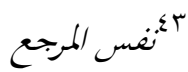

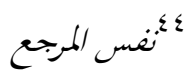

$$
\begin{aligned}
& \text { 0نغس المرجع المرجع }
\end{aligned}
$$


Al-Nahwu 'Inda al-Bashriyyiin...

$$
\begin{aligned}
& \text { في البصرة. تعلم على الخليل بعد إمام } \\
& \text { مذهب البصريين وكتابه في النحو هو لئي } \\
& \text { الكتاب. شرحه ابن السراج و والمرمان } \\
& \text { والسيرافن والرمانى. • • }
\end{aligned}
$$

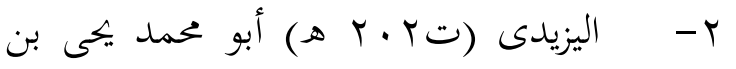

$$
\begin{aligned}
& \text { المبارك العدوى، أبو محمد اليزيدى كان } \\
& \text { مقرئا كما كان نحويا لغويا. } \\
& \text { r- أبو زيد (ت } \\
& \text { بن أوس بن ثابت الأنصارى الخرزمى كان }
\end{aligned}
$$

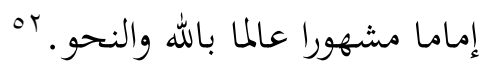

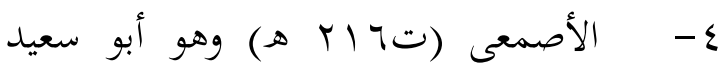

$$
\begin{aligned}
& \text { عبد الملك بن قريب الباهلى، ويقرر } \\
& \text { الخطيب البغدادى في تاريخه أنه كان دون } \\
& \text { أبى زيد الأنصارى في النحو والقواعد. ror }
\end{aligned}
$$$$
\text { ثالثا : الطبقة الخامسة البصرية }
$$$$
\text { - - الأخفش الأوسط (ت ال ال هـ) هو }
$$

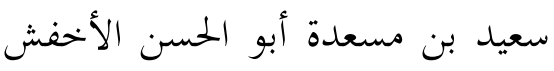$$
\text { الأوسط كان من تلاميذ سيبويه، }
$$$$
\text { وأعظم آثاره حفظه كاب أستاذه. }
$$

وروى عن الأخفش الأوسط أنه دخل بغداد وأقام بها مدة روى وصنف بها، وذلك بعد خذلان سيبويه في

$$
\begin{aligned}
& \text { •بولس براوزز، المنجدد فى الأعلام، بيروت : دار المشرق، }
\end{aligned}
$$

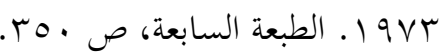

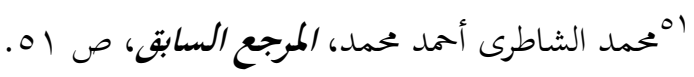

$$
\begin{aligned}
& \text { ror }
\end{aligned}
$$

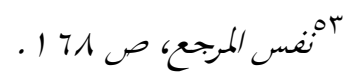

المناظرة المشهورة. وقد أراد أن يشار لاستاذه وزميله، فتحرش بالكسائى و سأله أمام تلامذته الفراء والأحمر وغير هما وخطأه فن إجابته حتى هم التلاميذة بالوثوب عليه ولكن السائى منعهم وأكرم مثواه، فأقام بالكسائى بنعم بالحياة الرغيدة وجعله مؤدب أولاده.

T- قطرب (ت T T T ه) هو أبو محمد

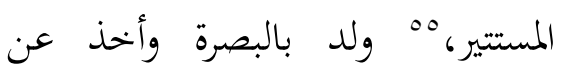
سيبويه وعيسى بن عمر الثقفى، ثم جعله هارون الرشيد مؤدبا لابنه الأمين.

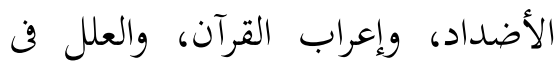

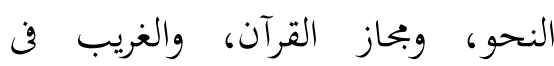
اللغة. البحو.

الدور الثالث : دور التضج والكمال أولا : الطبقة السادسة البصرية - الجرمى (ت TrO هـ هو أبو عمر

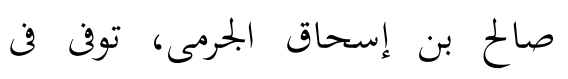
خلافة المعتصم.

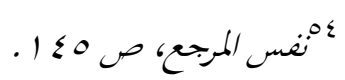

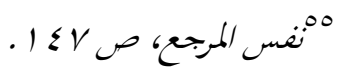

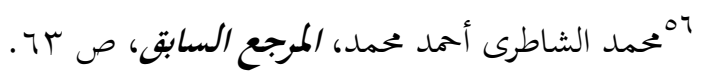

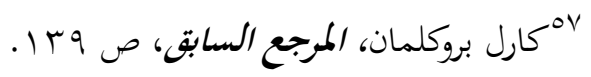

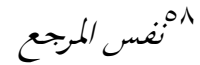




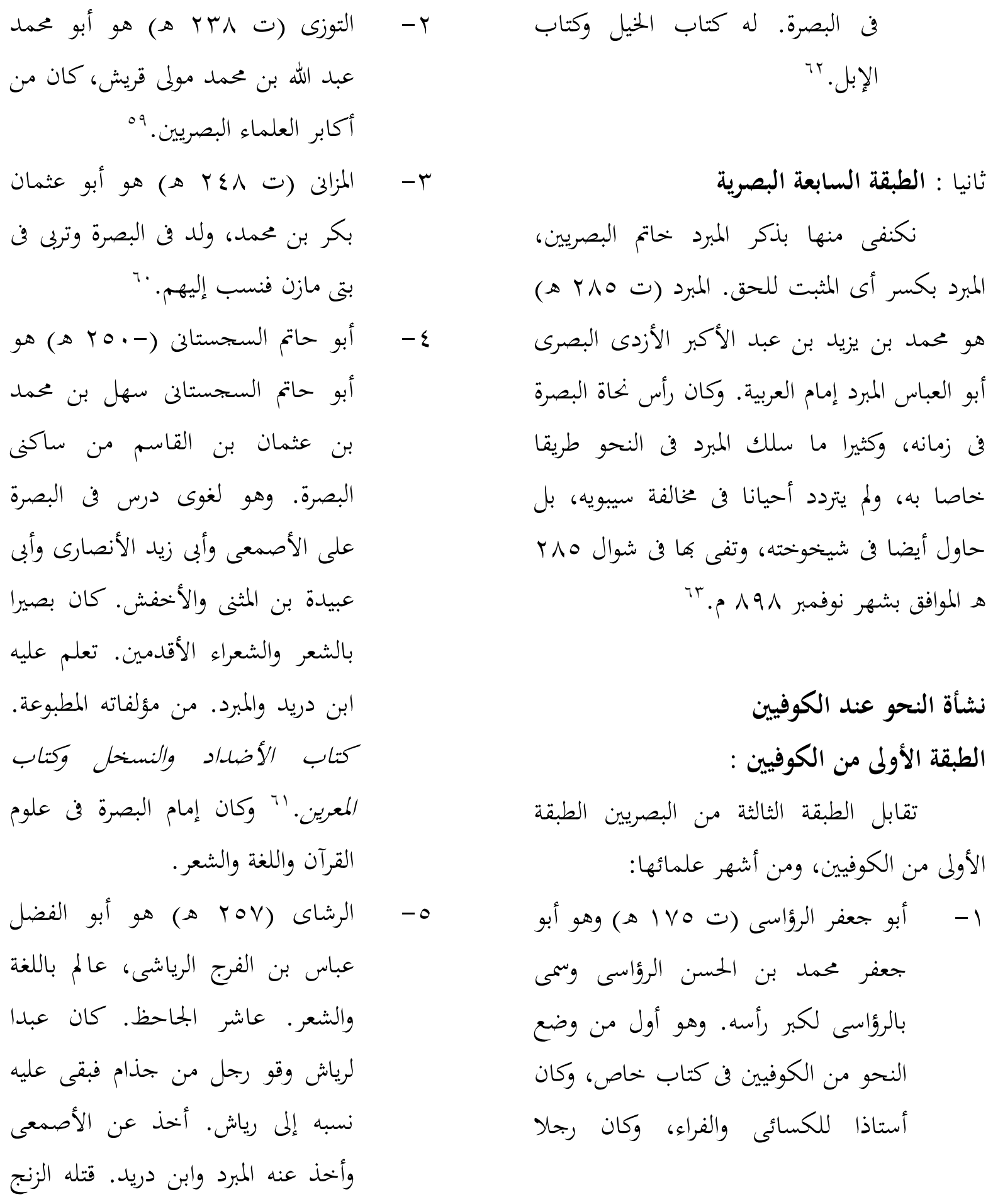

$$
\begin{aligned}
& \text { "09 محد الشاطرى أحمد محمد، المرجع السابق، ص } 70 .
\end{aligned}
$$

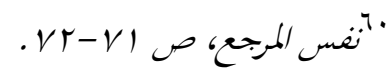

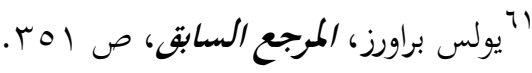


Al-Nahwu 'Inda al-Bashriyyiin...

$$
\begin{aligned}
& \text { صالحا. \& وقيل أيضا إن سيبويه إذا ذكر } \\
& \text { في كتابه الكوفى يعنى أبا جعفر الرؤاسى. }
\end{aligned}
$$

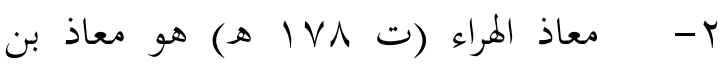

$$
\begin{aligned}
& \text { مسلم الهراء. }
\end{aligned}
$$

\section{الطبعة الثانية من الكوفيين :}

من أشهر اللماء في هذه الطبقة الكسائى، بل هو المؤسس الحقيقى لمدرسة الكوفة، ولذلك يكتفى بالحديث عنه في التمثيل لهذه الطبقة. لَّ وهو أبو الحسن على بن حمزة بن عبد الله بن عثمان الإمام أبو الحسن الكسائى إمام الكوفيين قى النحو بن بن واللغة وأحد القراء السبعة المشهورين. وسمى إنى بالكسائى لأنه أحرم في كساء وكان من أهل

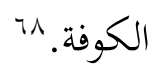

نشأ بالكوفة وتعلم في الكبر بعد لحنة لحنها

أمام جمع من طلبة العلم فلازم أئمة الكوفة حتى أنفذ ما عندهم، ثم خرج إلى الخليل فن البصرة وجلس في حلقته فأعجبه علمه فقال له :

من أين علمك هذا؟ قال من يوادى الحجار ونحد وتمامة فخرج إليها وأنفد خمس عشرة قنيئة حبر

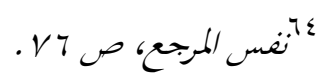

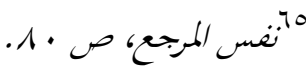

$$
\begin{aligned}
& \text { Trit }
\end{aligned}
$$

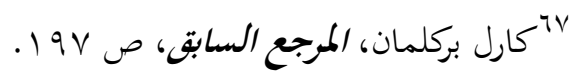

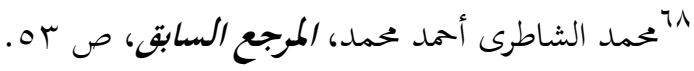

$$
\begin{aligned}
& \text { في الكتابة عن العرب سوى ما حفظه عنهم، وجعله } \\
& \text { الرشيد مؤدب ولده الأمين، وتفى بالرى سنة } 1 \text { 1 } \\
& \text { هـ. } 79 \\
& \text { الطبقة الثالثة من الكوفيين : } \\
& \text { - - الأحمر ·ت ع 19 هـ أبو الحسن } \\
& \text { بن على المبارك. •V من مؤلفات الأحمر }
\end{aligned}
$$

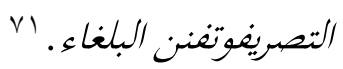

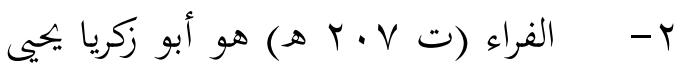$$
\text { بن زياد بن عبد الل ابن مروان الديلمى }
$$

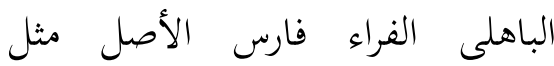$$
\text { الكسائى. }
$$$$
\text { وقال ثعلب : "لولا الفراء لما كانت }
$$$$
\text { اللغة لأنه خلصها وضبطها. ولولا الفراء }
$$$$
\text { لسقطت العربية، لانه تنازع ويدعيها }
$$$$
\text { كل من أراد، ويتكلم الناس على }
$$$$
\text { مقادير عقولهم وقرائحهم فتذهب. Vr }
$$

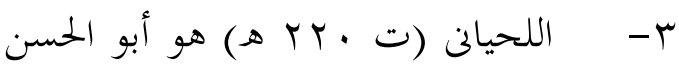$$
\text { على بن المبارك بن حازم اللحيانى من }
$$$$
\text { بتى لحيان، وقيل سمى بهذا لعظم }
$$$$
\text { V V }
$$

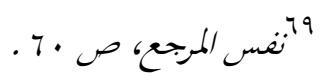

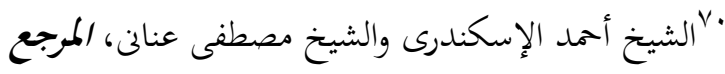

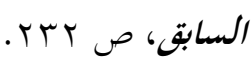

$$
\begin{aligned}
& \text { (ب) } \\
& \text { TrY }
\end{aligned}
$$

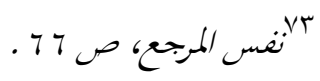

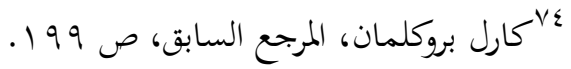


قال سلمة (ت TVI هـ) : كان

اللحيان أحفظ الناس للنوادر عن

الكسائى والقراء والأحمر. فمن نوادره

أنه حكى عن بعض العرب أهم يجزمون

بلن وينصبون يلم وعلى هذه اللغة قراءة

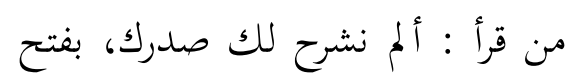

Vo. الحاء.

\section{الطبقة الرابعة من الكوفيين : الكوفين}

- - ابن سعدان (ت اسب هـ) هو أبو

جعفر محمد بن سعدان الضرير الكوفى

النحوى المقرئ. v4

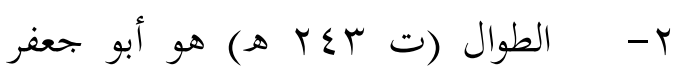

أحمد بن عبد الله بن قادم الطوال من

أهل الكوفة أحد أصحاب الكسائى. vv

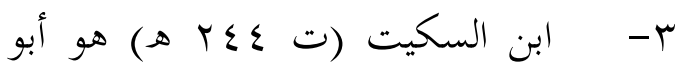

يوسف يعقوب بن إسحاق السكيت.

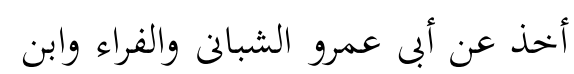

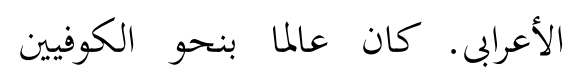

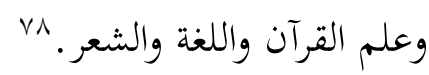

ع - الطبفة الخامسة من الكوفيين:

نكتفى بذكر خاتمهم ثعلب.
ثعلب (ت ا Y Y هـ) هو أحمد بن

يميى، إمام الكوفيين في النحو واللغة وله ثمانى

عشرة سنة أخذ عن الفراء، وصنف الكتب وله

ثلاث وعشرون سنة. V9 وكان ثعلب رأس نحاة

الكوفة والمبرد الذى يعاصره رأس نحاة البصرة فوقا

في الخلاف بين المذهبين باختلاف هذين

الرأسين. ‘ومن مؤلفات ثعلب : المقصور فن

النحو واختلاف النحويين ومعانى القرآن ومعانى

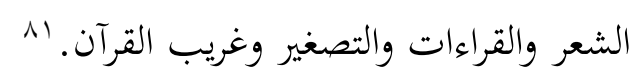

أجمع القدماء على أن نهو الكوفيين

بشكل مذهبا مستقلا أو كما نقول بلغة العصر

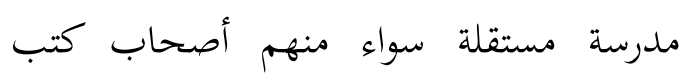

الطبقات والتراجم مثل ابن النديم في كتابه

الفهرست والزبيدى في كتابه طبقات النحويين

واللغويين وأصحاب كتب المباحث النحوية إذ

نراهم دائما يعرضون في المسائل المختلفة وجهة

النظر المتقابلتين في المدرستين: الكوفة

والبصرة.

والكوفيون لو سمعوا بيتا واحدا فيه جواز

شئ مخالف للأصل جعلوه أصلا وبوبوا عليه

بخلاف البصريين بل كثيرا مازادوا القاعدة بدون

رجوع على القاعدة نفسها، ولذلك كثرة الأقيسة والقواعد عند الكوفيين. واشتهر البصريون بأهم

$$
\begin{aligned}
& \text { نو } \\
& \text { 1/Vحمد الشاطر أحمد محمد، المرجع السابق، ص لمرجع } 70 .
\end{aligned}
$$

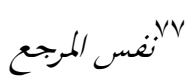

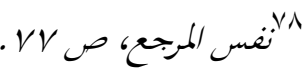

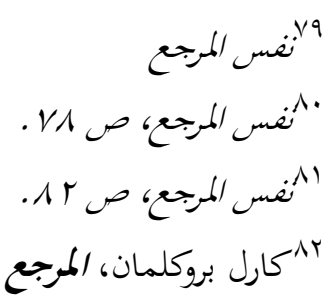


Al-Nahwu 'Inda al-Bashriyyiin...

$$
\begin{aligned}
& \text { أهل سماع، وأما الكوفيون فقد اشتهروا أفم أهل } \\
& \text { قياس. } \\
& \text { يقول الكسائى رئيس مدرسة الكوفة : }
\end{aligned}
$$

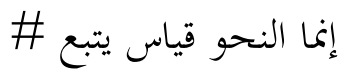

$$
\begin{aligned}
& \text { وبه في }
\end{aligned}
$$

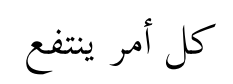

$$
\begin{aligned}
& \text { وليس معنى هذا أن البصريين لم يلجئو } \\
& \text { إلى القياس وأن الكوفيين لم يلجئوا إلى السماع، } \\
& \text { ولكن لما تحفظ البصرى وتشدد في أقسية تبعا } \\
& \text { للمسموع المعتمد عنده المقنن بضوابط وشروط } \\
& \text { سمى أهل سماع. ولما توسع الكوفى في القياس } \\
& \text { والمقيس عليه سمى أهل قياس حيث فتح ذراعيه } \\
& \text { لكل مسموع، ولذا قل الشاذ عند الكوفيين وكثر } \\
& \text { عند البصريين. } \\
& \text { والذى يعتبر المؤسس الحقيقى لمدرسة } \\
& \text { الكوفة بعد أن أخذت تلك المدرسة النحو من }
\end{aligned}
$$

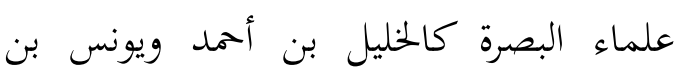

$$
\begin{aligned}
& \text { حبيب وغيرهما. ولعل أهم ما يميز المدرسة } \\
& \text { الكوفية من المدرسة البصرية اتساعها فن رواية } \\
& \text { الأشعار وعبارات عن جميع العرب بدويهم } \\
& \text { وحضريهم. ع } 1 \text { ـ } \\
& \text { وينبغى أن نعرف أن الكوفيين لم يقفوا } \\
& \text { بقياسهم عند ما سمعوه ممن فسدت سلائقهم } \\
& \text { من اعراب المدن أو ما شذ على ألسنة بعض } \\
& \text { أعراب البدو وقد اسخدموا القياس أحيانا بدون } \\
& \text { إسناد إلى أى سماع، على سبيل المثال قياسهم } \\
& \text { العطف بلكن في الإيجاب على العطف ببل في } \\
& \text { مثل : قام زيد لكن عمرو بدون سماع عن العرب } \\
& \text { يجيز لما هذا القياس. } \\
& \text { وينبغى أن يستقر في الأذهان أن } \\
& \text { المدرسة الكوفية لا تباين المدرية البصرية من تلك } \\
& \text { الأركان التى ظلت إلى اليوم راسخة فن النحو } \\
& \text { العربى، غير أها مع اعتمادها لتلك الأركان } \\
& \text { استطاعت أن تشق مذهبا جديدا له طوابعه } \\
& \text { ومبادؤه. } \\
& \text { الحخلاف بين البصريين والكوفيين فى النحو } \\
& \text { - - اشترط البصريون لعمل الوصف } \\
& \text { الاعتماد على نفى أو استفهام لفظا أو } \\
& \text { تقديرا ولما جاء على خلاف هذا قول } \\
& \text { حاتم الطائى (ت 7 ؟ هـ) } \\
& \text { خبير بنو لمب فلا تك ملغيا تحبـ } \\
& \text { مقالة لهبى إذا الطير مرت } \\
& \text { أولوه بأن خبير خبير مقدم، وهو وصف } \\
& \text { يستوى فيه الأفراد وعدمه وجعلوا بنو لهب } \\
& \text { مبتدأ مؤخرا، لا فاعلا. وأما الكوفيون فلم } \\
& \text { يشترطوا هذا، ولذا صح عندهم فاعلية بنو } \\
& \text { لهب بالوصف خبير مع كونه غير معتمد. } 14 \\
& \text { r - أوجب البصريون تذكير الفعل مع جمع } \\
& \text { المذكر السالم وتأنيثه مع جمع المؤنث }
\end{aligned}
$$

$$
\begin{aligned}
& \text { كَمحمد الشاطر أحمد محد، المرجع السابق، ص بrم. } \\
& \text { ع^ممد الشاطر أحمد محد، المرجع السابق، ص مبر. }
\end{aligned}
$$

$$
\begin{aligned}
& \text { 10شوقى ضيف، المرجع السابق، ص } 100 .
\end{aligned}
$$

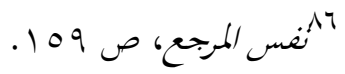


السالم. وجوز الكوفيون التذكير

والتأنيث : لما جاء قوله تعالى : آمنت

به بنو إسرائيل (يونس: •ج))، وكذا هوالهال

قول عبدة بن الطيب (ت م ب هـ)

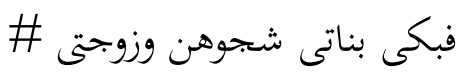

$$
\text { والظاعنون إلى تم تصدعوا }
$$

لجأ البصريون إلى التأويل فقالوا: إن الجمعين لم

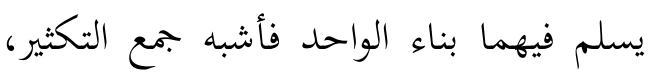

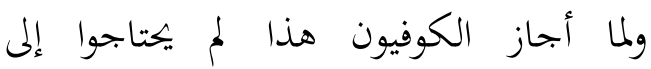

$$
\text { التأويل. }
$$

r- - الاسم مشتق من السمو عند البصريين،

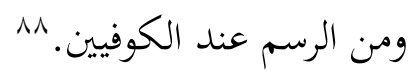

ع - الفعل مشتق من المصدر عند البصريين،

والمصدر مشتق من الفعل عند الفند

$$
\text { الكوفيين. } 19
$$

ه - - منع البصرييون نيابة الظرف والجار

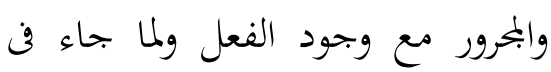

القرآن الكريع : ليجزى قوما بما كانوا

يكسبون (الجاشية : ع ()، إذ قال

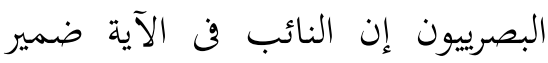

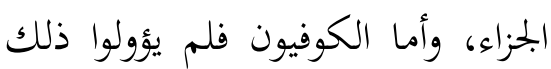

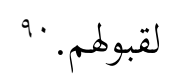

$$
\text { لنفس المرجع، ص ع } 17 .
$$

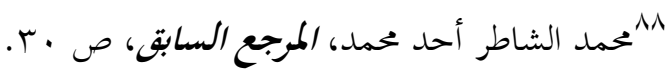

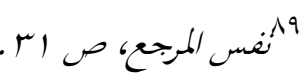

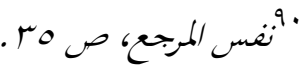

7- - القول في هلم جرا، كلام مستعمل في

العرف كثيرا، وذكر أبو بكر الأنبارى في

كتابه الزاهر وبسط القول فيه، وقال :

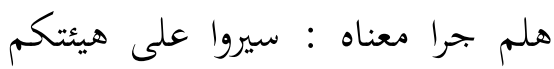

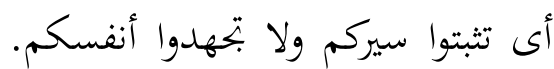

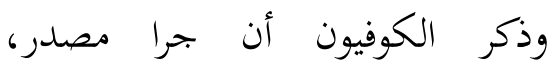

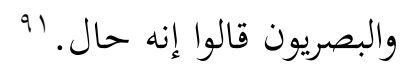

- V - V اشترط البصريون في التمييز وجوب

التنكير، ولما جاء قول رشيد ابن

شهاب : رأيتك لما أن عرفت وجوهناء تول ريدا

صدرت وطبت

النفس باقيس

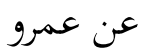

قالوا : إنه ضرورة، أما الكوفيون فقد

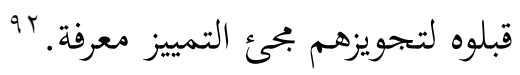

م- - اشترط البصريون في المؤكد أن يكون

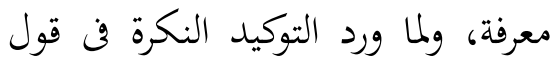

عبد الله بن مسلم بن جند المذلى :

لكنه شاقة إن قيل ذا رجب ل

يا ليت

عدة حول كله رجب

انكروا هذه الرواية وقالوا إن الرواية الصحيحة :

حولى، وعلى فرض صحة هذه الرواية فالبيت

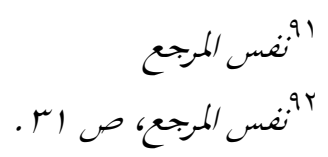


Al-Nahwu 'Inda al-Bashriyyiin...

$$
\begin{aligned}
& \text { ضرورة. rه وأما الكوفيون فقد قبلوه لأفم جوزوا } \\
& \text { تأكيد النكرة إذا كانت محددا كما هي هنا. ؟9 } 9 \\
& \text { 9- - منع البصريون إظهر (أن) بعد (كى) } \\
& \text { ولما اعترض بقول الشاعر : }
\end{aligned}
$$

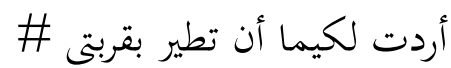

$$
\text { فتتركها شنا يبداء بلقع }
$$

قالوا إن قائله غير معروف أو ضرورة، أما الكوفيون

$$
\text { فقد قبلوه.90 }
$$

•

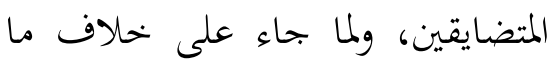

قالوا قوله تعالى: فلا تحسن الله مخلف

وعده رسله (الأنعام: VV I I) في قراءة

نصب (وعده) وجر (رسله) لإضافة

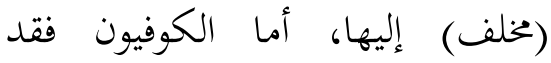

أجازوا هذا، لأن القراءة بها وردت.

11 - أجاز الكوفيون إضافة كذا إلى مفرد أو

جمع قياسا على العدد الصريح ولم يجز

البصريون هذا لعدم السماع، في سياق

منع البصريون هذا : خلافا للكوفيين

أجازوا في غير تكرار ولا عطف أن

$$
\begin{aligned}
& \text { "9 ابن هشام الأنصارى، المسائل السفرية، بيروت : مكتبة }
\end{aligned}
$$

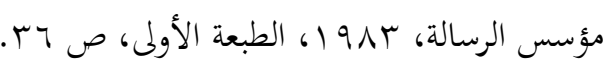

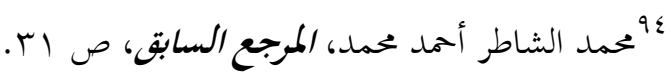

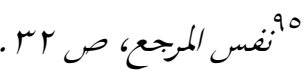

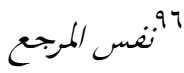

يقال : كذا ثوب وكذا أثواب قياسا على العدد الصريح.

r إ- والاسم الذى فيه التاء كطلحة لا يجمع جمع مذكر سالما عند البصريين وقد أجاز الكوفيون جمعه. 91

با- جوز الكوفيون تثنية أجمع وبماء

وتوابعهما قياسا على جمعهما وتبعهم في هذا الأخفش (ولم يجز معظم البصريين ذلك لفقدان السماع)، ويقول الرضا : وقد أجاز الكوفيون والأحفش لمثنى المذكر أجمان، أكتعان، أبصعان،

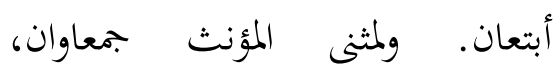
كتعاوان، بصعاوان، بتعاوان، وهو عير 99.90 ع ا- أمامك زيد وفى الدار عمر : فاحتج الكوفيون بأن قالوا إن الأصل في قولك

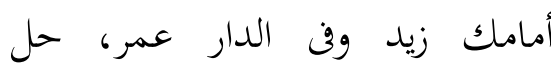
أمامك زيد وحل في الدار عمر فحذف رئ الفعل و واكتفى بالظرف منه. و وأما البصريون فاحتجوا بأن قالوا إنما قلنا إن الاسم بعده يرتفع بالابتداء لأنه قد بـ لـ يعرى من العوامل اللظية. '.'

$$
\begin{aligned}
& \text { نو نوس المرجع }
\end{aligned}
$$

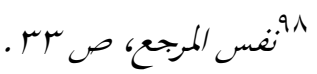

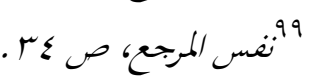

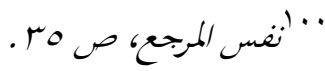




\section{الخلاصة :}

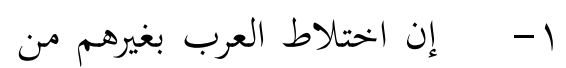

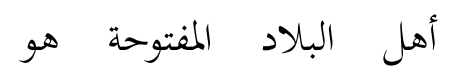

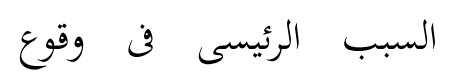

اللحن في اللغة العربية، كما

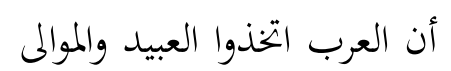

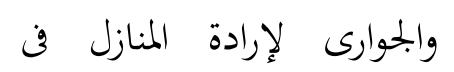

العصر الإسلامى المبكر. وقد

روي أن رجلا لخن أمام

الرسول الله صلى الله عليه

وسلم : أنه قال لأصحابه

ارشدوا أخاكم فإنه قد ضل.

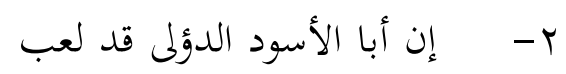

دورا كبيرا فن وضع علم

النحو، سواء من أمر نفسه أو

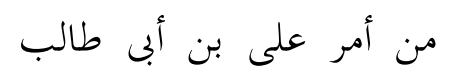

كرم الله وحهه أو من أمر عمر لمر بن

بن الخطاب أو من أمر زياد

وهم كانوا على علم بمعرفة أبى إيى

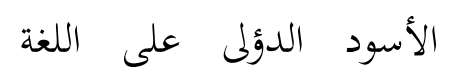

$$
\text { العربية. }
$$

r- تبدأ الطبقة العلماء على أن

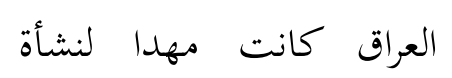

النحو العربى ومدينة البصرة

هى مقر نشأته الأول قبل

الكوفة بقرن من الزمان.

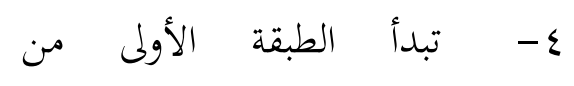

البصريين بين من عهد نصر

بن عاصم (ت 9 م هـ) وتبدأ
الطبقة الأولى عند الكوفين فن

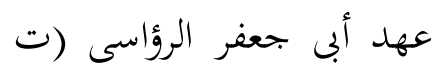

$$
\text { (\$) 1 Vo }
$$

0- - - إن المبرد وتعلب هما يمثلان

مدرستى البصرة والكوفة في

آخر القرن الثالث الهجرى،

وقد جرى بينهما مناظرات

علمية ولكل منهما شيعته

وحزبه. 
